\begin{tabular}{|c|c|c|}
\hline & JSM (10) (1) & 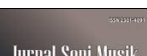 \\
\hline & JURNAL SENI MUSIK & \\
\hline & https://journal.unnes.ac.id/sju/index.php/jsm/index & \\
\hline
\end{tabular}

\title{
NGERONCONGI AND NGEPOP: A STUDY OF POPULAR SONG'S VOCAL PERFORMANCE IN KERONCONG MUSIC IN SEMARANG
}

\section{Fauziatus Zilmi}

Fakultas Bahasa dan Seni, Universitas Negeri Semarang

Abdul Rachman ${ }^{\bowtie}$

Fakultas Bahasa dan Seni, Universitas Negeri Semarang

Moh. Muttaqin

Fakultas Bahasa dan Seni, Universitas Negeri Semarang

\begin{tabular}{l} 
Article Info \\
\hline Submitted: May, 2021 \\
Revised : May, 2021 \\
Accepted : June, 2021
\end{tabular}

Keywords: ngeroncongi, ngepop, vocal performance, popular songs

\begin{abstract}
Keroncong Music is a music that has different character from other musics, including several techniques in vocal performance, such as luk, nggandul, embat, gregeland cengkok. Nowadays keroncong music does not only perform keroncong songs but also performs popular songs accompanied by keroncong music. When performing popular songs accompanied by keroncong music, usually the performance of each singer will be different. This study aims to determine how the vocal performance of popular songs in keroncong music. The research method used was qualitative. Data collection techniques used observation, interviews, and document study. The results showed that in performing pop songs with a slow tempo accompanied by keroncong music, the techniques used by keroncong singers tended to be Ngeroncongiwhich means that singers still use some keroncong singing techniques such as luk, nggandul, embat, gregel, and cengkokalthough the songs performed have pop genre. Whereas in performing pop songs in fast tempo that are accompanied by keroncong music, the techniques used by keroncong singers tend to pop (ngepop), which means the singers still show pop techniques and improvisation.
\end{abstract}




\section{INTRODUCTIONS}

Indonesia is rich in types of traditional music that grow and develop in all corners of the country. Traditional music is a manifestation of cultural values that are used in accordance with tradition (Sedyawati; 1992). In line with Sedyawati, according to Tumbijo (1977) traditional music is an art culture that has been created for a long time, is hereditary and developed, and has lived in certain areas. There are various kinds of traditional music developed in Indonesia, including dangdut, gamelan, angklung, talempong, keroncong, and so on.

Keroncong music was the dominant type of popular music in Indonesia before independence, at least between 1915 and 1935. The origin of keroncong music in several studies states that it is originated from Portugal via ships of sailors in the 16th century and anchored in the archipelago. Sailors brought music called fado to entertain themselves during the trip. Fado is music that is popular in the Portuguese. It is in the form of songs used to accompany dances, fado is a small guitar musical instrument called cavaquinho which later entered Indonesian territory and evolved into Ukulele. Ukulele is a small string instrument or what is commonly called a four-string ukulele. This musical instrument is the root of the emergence of keroncong music and with its development through several phases, this music has become the original musical identity of Indonesia with the instruments used today, namely the cuk (ukulele), cak (banyo), guitar, cello, bass, violin, and flute. (Mauly \& Ben, 2006, h.54); Ganap, 2006); Ganap, 2011); Soeharto \& Achmad Soenardi, 1996;Kornhauser, Bronia; Kartomi, 1978; Kornhauser, 1984).

According to Harmunah (1987), keroncong is an interpretation of the sound of an ukulele instrument that is played in arpeggio (resqueadoSpanish) and delivers a "crong-crong" sound and finally, the term keroncong arises, while according to Soeharto (1996) keroncong music is a type of traditional music playing with a diatonic scale using the accompaniment of several stringed musical instruments that are played with certain rules so that it becomes a characteristic of the music itself. Then according to Mauly \& Ben (2006), the characteristic of keroncong style is the playing of two small stringed instruments (e.g. mandolin and ukulele) that complement each other in crochet, this playing is often called cak-cuk : as if one played cak and the other replied cuk. From several opinions regarding keroncong music that have been mentioned, it can be concluded that it is a playing of ukulele which sounds "crongcrong" and is played with certain rules that characterize the music.

A part from its characteristic, keroncong songs also have different forms and become the identity of keroncong music. According to Harmunah (1987), keroncong music is divided into four groups: (1) original keroncong, (2) langgam, (3) stambul, and (4) extra songs. Meanwhile, according to Kornhauser (1984), keroncong music is divided into five groups: (1) original keroncong, (2) stambul, (3) langgam keroncong (4) langgam Jawa, and (5) keroncong beat. Each form has a different way of singing and character (V Ganap, 2011; Harmunah, 1987, 1996; Victor Ganap, 2020; Soeharto, 1996a).

The way to sing and the character of singing keroncong is different from other music because there are several techniques in singing that must be applied when singing keroncong, here are the various techniques in keroncong singing, the first technique is luk, luk is a decorative tone or a type of legato sung with a curve before going to the tone it should be (Finalti, 2012). The other technique is nggandul. Nggandulis a drop of tone that is deliberately made inaccurately on the pulse or beat of the rhythm but deliberately made a little too late in order to get a good swing (Soeharto, Ahmad \& Samidi, 1996, h.101). The next technique is ngembat or portamento. It is a way of singing that begins with a few hertz (high and low volume) below the main tone, regularly leading to the main tone (Sanjaya, 2010). Embat technique in western classical music term is called appoggiatura. The fourth technique is gregel, it is a decorative-moving fast tone. The way to sing this technique is by bouncing the notes above the original tone quickly but still flexible. Gregel in classical music is called mordent(Pambajeng et al., 2019, pp.34-35). The last technique is cengkok. It is all about decorative tones that developing the song's phrases meaning it fills, beautifies, enlivens the song's phrases. It is called improvisation. Cengkok in classical music is called gruppetto (Sanjaya, 2010).

Nowadays keroncong performances have experienced many developments, many keroncong orchestras, musicians, and keroncong music figures have made innovations in presenting keroncong music with the aim of maintaining and preserving the keroncong music itself, including the collaboration of keroncong music with other music genres. Rachman \& Utomo (2018), Ramadhani \& Rachman (2019), and (Sanjaya, 2018) which revealed that there were innovations in the form of performances in 
the form of collaborating keroncong music with other types of music, namely the form of Keroncong Jazz (Cong Jazz), Keroncong Rock (Cong Rock), Keroncong Orchestra (Congkestra) and the addition or use of wind instruments such as oboe, a brass section in keroncong music performances. Furthermore, Rachman\&A'yun (2019) explained the innovation of keroncong music called Keroncong in Jamaican Sound, which is keroncong music that is collaborated with ska, rocksteady, reggae music. There are also those who adapt the accompaniment pattern of keroncong music with the accompaniment pattern of other music genres such as Javanese langgam, bossanova, cha-cha, polka (Rachman \& Utomo, 2019; Putra et al., 2021). Fauziah \& Rachman (2020, h.40) also explained the innovation in presenting keroncong music package, it is by developing vocal arrangements in the songs presented, both keroncong songs and other genre songs. In addition, ways that can be done in promoting keroncong activities are by broadcasting keroncong music live on Radio Republik Indonesia (RRI) Semarang, Gebyar Keroncong performances and keroncong music competitions which can increase public interest in this music. (Rachman \& Pribadi, 2019). There are also those who innovate keroncong songs by developing harmonization elements, tone ranges, melodies, lyrics, and rhythms. (Rachman, 2013; Rachman et al., 2019; Rachman \& Lestari, 2013).

In addition to innovations in collaborating other types of music in keroncong music and developing keroncong music with vocal arrangements, there are also other innovations in the form of carrying out other genres of songs such as popular songs performed with keroncong music accompaniment. Currently, there are a lot of keroncong music performances that not only present keroncong songs such as keroncong style, original keroncong, stambul but also present songs that are popular in society such as Indonesian pop songs, western pop, rock, Korean pop, and so on. This is done to attract keroncong music lovers and make the public enjoy keroncong music, especially teenagers.

According to Shuker (1998), a pop song is a song that emphasizes the chorus or song repetition, uses fun song lyrics with a romantic theme, and is commercially oriented. According to Purba \& Pasaribu (2006), popular music is easy to grow in Indonesia because the material in popular music can always create new products that can be accepted by the public. Popular songs have a characteristic that is singing using a lot of improvisation. Witkin (2003; 2013)states that in popular music, the details described are in the form of ornamentation such as chord sequences, harmony, melodic themes, rhythmic motifs, rest. Pop music is the result of a cultural industry that is dominated by standardization or it can be interpreted that the more similarities and individualizations of all differences are accidental. (Srinati, 2007, h.70-76). The more standardized songs, the more ears are individualized. Standardization in songs is referred to the similarity of the musical parts, musical form, and chords. Pseudo-individualization disguises the music by making it more varied and different from the others.

Based on the author's observations on keroncong music performances today, it is less attractive to the public. According to (Rachman \& Utomo, 2018a)Keroncong music is getting less and less attractive to the public because of the assumption that keroncong music is no longer relevant in the present era. This makes keroncong music performers carry out many innovations in keroncong music performances to attract public interest in an effort to maintain and preserve keroncong music. One of them is by presenting popular songs during keroncong music performances. Keroncong singers perform trending songs with keroncong music accompaniment, both Indonesian pop, western pop, rock and so on. The real phenomenon is that keroncong singers have different performances in singing popular songs with keroncong music accompaniment. According to Soeharto, Ahmad \& Samidi (1996, h.93-94). There are 4 kinds of songs performance, they are appreciation, dynamics, tempo, and analysis of the song. Appreciation is a description of emotion in the form of sadness, lamentation, anxiety, restlessness or joy, and so on. Dynamics is the loudness and the softness of the voice when singing and usually listed in scores. The tempo is usually written at the beginning of the song and what needs to be considered is the pulse, beat or maat. Song analysis in the form of a singer is able to analyze the song well for reading and memorizing so that it can be performed with full concentration.

Research on keroncong music and keroncong vocals has been conducted by previous researchers, such as research by Ayunda, Gustina \& Virgan (2013) which states that keroncong music produced from each community can show differences from one another, such as the arrangement of instruments, patterns or techniques of instrument play, harmonization or vocal style, where each of these elements can be obtained from a variety of musical and nonmusical experiences that are obtained significantly both formal and non-formal in their social environment. Pranadjaja (1976) discusses the basic vocal techniques, correct posture when 
singing and how to apply them during practice. Further research by Siswati (2019) discusses the factors that make a sindhen comes into the popular realm which aims to be increasingly in demand by the wider community and to maintain its existence in the music industry. The study conducted by Nadya Rany Sekar Pambajeng, Suryati \& Musmal (2019) discusses the difficulty of keroncong singers in performing keroncong stambul songs, it is to sing in a soft and smooth but still resonant way.

The author has reviewed several previous studies and there are studies related to the author. This research is research by Nadya Rany Sekar Pambajeng, Suryati \& Musmal (2019) which discusses the difficulty of singing keroncong stambul songs, it is singing softly and smoothly but still resonating. Each singer has a style, character, and vocal technique that has its characteristics in performing keroncong songs, and in this study, in general, it is almost the same as keroncong in general, such as gregel, cengkok, embat, and nggandul, but there are some differences in the way they are performed. From the study, there is a similarity and difference with Nadya, Suryati \& Musmal's research. The similarity is that both discuss the technique and vocalization of songs with keroncong music accompaniment. The difference is that the research focuses on the technique and vocal performance of one song entitled Stambul Tinggal kenangan by Budiman BJ while the researcher focuses on the vocal performance of popular songs by several singers in Semarang.

\section{METHODS}

The method used in this research is a descriptive qualitative method. This method is carried out by explaining the phenomena that occur in the context of the research, describing it in the form of written words obtained from observations on the phenomenon to determine the vocal performance of several singers in performing popular songs to musical accompaniment in Semarang and poured in depth according to the theoretical basis there is. The object of the study is Keroncong Singer in Semarang that sing a popular song by using keroncong music accompaniment.

The data collection used three techniques, they are observation, interview, and document study. The methods of observation were held by observing, scrutinizing, understanding the phenomenon that was done by directly exploring information about the performance of various singers in performing a popular song in keroncong music accompaniment, then describe it. The second technique is an interview. It was done by interviewing some respondents, they are Keroncong singer in Semarang. The document study was by collecting information such as written documents, pictures, videos. The data validity technique used source triangulation, method, and theory. The collected data was then analyzed in three steps; reduction, presentation, and conclusion.

\section{RESULTS AND DISCUSSION}

Keroncong music has developed from era to era. Starting from the development of the form of the performance, the pattern of the accompaniment, the instrument, and the development of the songs performed. Nowadays, keroncong music does not only perform keroncong songs. Nowadays, keroncong music does not only perform keroncong songs, such as langgam keroncong, keroncong asli (original keroncong), and stambul, but also perform popular songs, such as pop, dangdut, rock, reggae, and so on. That is done by keroncong music's player to attract the interest of society toward keroncong music. This chapter will discuss two popular songs that are often performed using keroncong orchestra by two singers. The title of the songs are Jaga Selalu Hatimu that is popularized by Seventeen band, and Prahara Cinta by Hedi Yunus. The two singers are Julio Ardy and Zahrotul Fauziah. The authors choose those two songs and those two singers because they can represent everything in the study about the performance of popular song vocal with keroncong music accompaniment. Those two songs are very popular and are often sung by Indonesian singers including keroncong singers in Semarang.

\section{The Performance of Popular Song Vocal with Keroncong Vocal Technique}

One of the popular song that is often performed by keroncong singers in Semarang is "Jaga Selalu Hatimu" by Seventeen band. This song is performed by Julio Ardy, one of keroncong singer in Semarang. This song was presented in keroncong performance-themed "Pentas Keroncong DISBUDPAR \& Hamkri Kota Semarang" in 2020. In this part, the vocal performance of Julio Ardy in singing "Jaga Selalu Hatimu" used keroncong vocal techniques, such as luk, nggandul, embat, gregel, and cengkok, and Pop singing technique such as improvisation. In Jaga Selalu Hatimu song, Julio Ardy sings with luk technique. It means that there are added tones 
before the main tones, the ones that are usually used when singing keroncong songs. The discussion about luk technique used by Julio Ardy can be seen below:

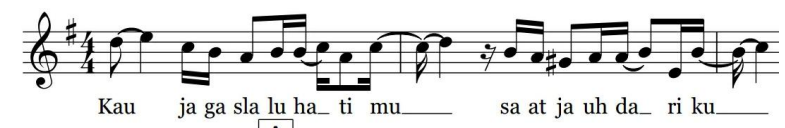

Figure 1. Part of Jaga Selalu Hatimu (Julio Ardy)

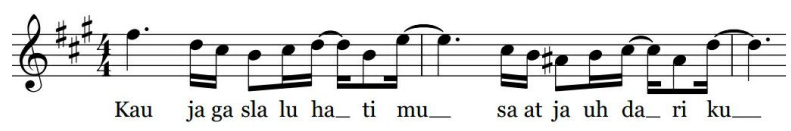

Figure 2. Part of Jaga Selalu Hatimu (Seventeen)

Based on Figures 1 and 2, it can be seen the difference in how the song is sung. It is showed by the song melody in the words "kau" ,"mu", "da" "dari", and "ku". The syllable "kau" in picture 1 is directly sung in Fis tone or 3 sharp tones, while in picture 2 it uses $\mathrm{D}$ tone before $\mathrm{E}$ or Sol before La in one-sharp scale. Luk technique is also used by Julio Ardy in the syllable of "mu", "da" and "ku". From the above example, there are some phrases sung by Julio Ardy using luk technique. It is a decorative tone similar to legato sung by curving it before the main tone (Finalti, 2012; Sanjaya, 2010).

The next vocal keroncong technique used by Julio Ardy in singing Jaga Selalu Hatimu song is nggandul. This technique is singing to the beat slower than it should be so it has the impression of being late or is behind the beat it should be.

The following is an example of nggandul technique by Julio Ardy:

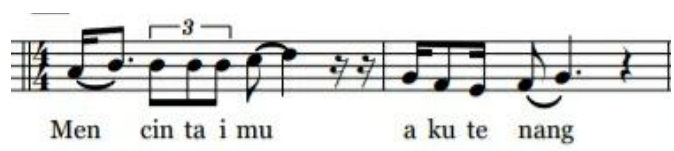

Figure 3. Part of Jaga Selalu Hatimu (Julio Ardy)

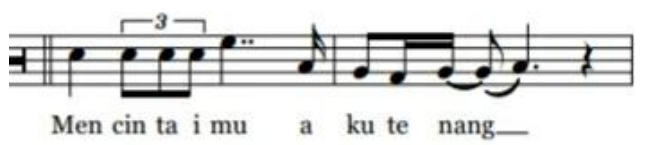

Figure 4. Part of Jaga Selalu Hatimu (Seventeen)

Based on the part of song notation in figures 3 and 4 , it can be seen that the way the singers sang is different. The differences are on the beat from the word "aku", at the time frame of 13. Seventeen Band sings "a" in "aku" at the twelfth time frame fourth beat, while Julio Ardy sings "a"in "aku" at the first beat in the thirteenth time frame. This indicates that Julio Ardy uses nggandhul technique in that part. It is one beat slower than it should be.

Julio Ardy did not use other keroncong singing techniques such as embat, gregel, and cengkok in singing the song Jaga Slalu Hatimu, because according to him not all keroncong singing techniques can be applied and are suitable for popular songs. The embat technique is a technique by bouncing a note at the end of a sentence and this technique is not used because its use is more difficult for popular songs, it's just that at the end of the phrase, Julio Ardy uses a long, soft dynamic vibration which is almost the same as the vibration in keroncong singing. Julio Ardy also didn't use the gregel technique in performing this song because Julio Ardy did not all change his pop vocals into keroncong or what is commonly referred to as "ngeroncongi" by keroncong musicians and singers.

Next is a discussion by linking a touch of pop improvisation to the way Julio Ardy sings in singing popular songs with keroncong music accompaniment. In some parts by comparing the singer of the band Seventeen, the original improvised performance of the original singer was not imitated by Julio Ardy and his character tended to be more keroncong technique with a tunable voice. For more details, see the melody piece of the song in the image below:

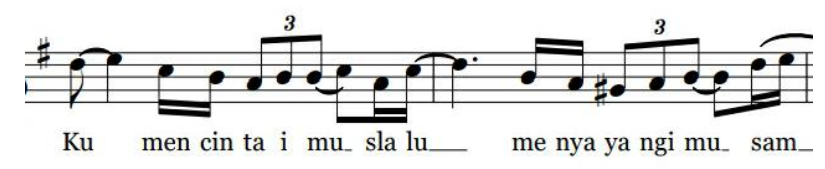

Figure 5. Part of Jaga Selalu Hatimu (Julio Ardy)

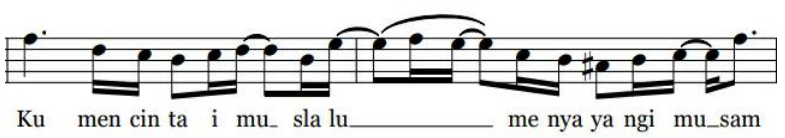

Figure 6. Part of Jaga Selalu Hatimu (Seventeen)

Based on pictures 5 and 6 above, it can be seen that Julio Ardy sings the syllables "lu" in "slalu" with luk touch such as the keroncong technique, which is to get an additional note before the main tone, namely adding the $\mathrm{E}$ note before the $\mathrm{D}$ note or the Fatone to the Sol tone on the 1 sharp scale $(G=$ do), while the singer of Band Seventeen sings the syllable "lu" in "slalu" with improvisation, it is by adding additional notes after the main tone then dropping back to the main tone, namely with the main tone $\mathrm{E}$ then to Fisand then down again to $\mathrm{E}$ or Sol tone to $\mathrm{La}$ tone then down again to the Sol tone (scale 3 sharp $\mathrm{A}=\mathrm{do}$ ). 
The original tempo of the song Jaga Selalu Hatimu performed by the band Seventeen is $68 \mathrm{bpm}$, which tends to be slow like the tempo of most keroncong songs. However, when this song was performed by Julio Ardy using keroncong music accompaniment, the tempo was slowed down again to $52 \mathrm{bpm}$. Julio Ardy's singing style which tends to be tunable can affect the tempo to be slower than the tempo of the original version.

The song Jaga Selalu Hatimu tells of the happiness of loving someone sincerely because you have kept your heart, made you smile, and made your life more meaningful. Julio Ardy sang the song Jaga Selalu Hatimu in a good and serene performance so that the contents of the song were conveyed to the audience. Seen from the point of view of the dynamics or the loudness of the voice in singing a song, there are differences in the singing behavior of the singer of the band Seventeen and Julio Ardy in performing the song Jaga Selalu Hatimu. The singer of the band Seventeen sang this song, on the chorus, there was an emphasis and louder in singing while Julio Ardy performed it more gently and tunably which was in line with the singing character of kerocong songs. Thus it can be seen that Julio Ardy's character when singing popular songs with a slow tempo (tempo that is identical to keroncong songs in general) has a touch of some keroncong singing techniques or what is commonly referred to in the keroncong community with the term "ngeroncongi".

\section{The Performance of Popular Song Vocal with Pop Vocal Technique}

The next popular song most often performed by keroncong singers in Semarang is a song with the title "Prahara Cinta" which was popularized by national singer Heidi Yunus. This song was performed by one of the Semarang keroncong singers named Zahrotul Fauziah during a keroncong performance in the "DISBUDPAR \& Hamkri Semarang Keroncong Performance" in 2020. The vocal performance performed by Zahrotul Fauziah when singing the song PraharaCintais associated with vocal techniques in keroncong music, they are luk, nggandul, embat, gregel and cengkok, as well as pop vocal technique improvisasi pop (pop improvisation) in singing.

The performance of Zahrotul Fauziah's vocals when singing the song Prahara Cinta are applying techniques such as techniques in kerocong, namely techniques of $l u k$, in the form of additional notes before going to the main tone, but the luk technique is a little different from the luk technique in keroncong music, here is the explanation:
Figure 7. Part of Prahara Cinta (Zahrotul Fauziah)

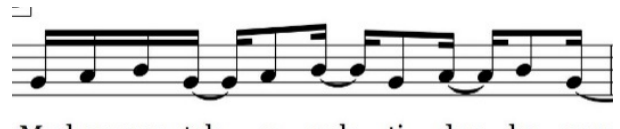

Ma kan pun tak_ e nak_ ti dur_ ku pun

Figure 8. Part of Prahara Cinta (Hedi Yunus)

In the notation of how to sing the song, Zahrotul Fauziah and Heidi Yunus have differences, namely in the syllables "nak" in "enak", the tone performed by the original singer is direct to the B tone, at the $4 \mathrm{Mol}$ scale while Zahrotul Fauziah sang it with an additional D tone to $\mathrm{E}$ at 2 sharp scales. This is in line with the definition of $l u k$ that the additional tone before the real tone sung by Zahrotul Fauziah. But the luk technique used by Zahrotul Fauziah is not sung in a melancholy manner like the use of the luk technique on keroncong, but is more strictly carried out like a pop singing style.

The other techniques in keroncong, such as nggandul, embat, gregel, and cengkok are not used by Zahrotul Fauziah when singing Prahara Cinta with keroncong music accompaniment. These were not used because according to Zahrotul Fauziah, singing popular songs that have a fast tempo is still maintains the style of singing popular songs even though the accompanying music is in the form of keroncong music, besides keroncong singing techniques such as nggandul, embat, gregel, and cengkok. It is very difficult to apply, especially to fast tempo pop songs that it is very opposite to the tempo that tends to be slow in keroncong songs. Zahrotul Fauziah's vocal performance when associated with pop improvisation is different from the song Prahara Cinta performed by Heidi Yunus, the following is the explanation:

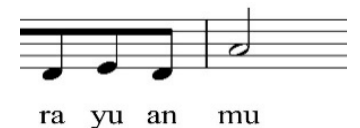

Figure 9. Part of Prahara Cinta (Zahrotul Fauziah)

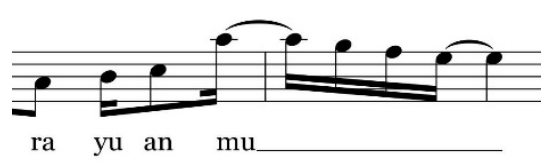

Figure 10. Part of Prahara Cinta (Hedi Yunus)

Based on figures 9 and 10, it can be seen that Zahrotul Fauziah performed the syllable "mu" with only one tone, namely the tone A or Sol in a 2 sharp scale, while improvisation occurred in the character of Hedi Yunus when singing the syllable "mu", namely developing the

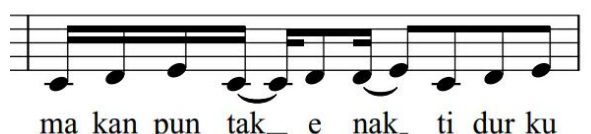


tone. In essence, the development of the notes is the sequence of the notes as / do, g / si, f / la, and es/sol (on a scale of $4 \mathrm{~mol}$ ).

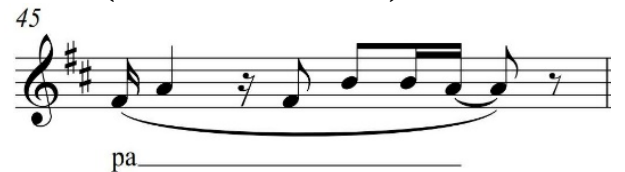

Figure 11. Part of Prahara Cinta (Zahrotul Fauziah)

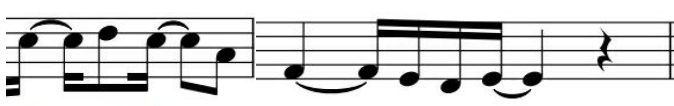

dan_tak lu_ pa

Figure 12. Part of Prahara Cinta (Hedi Yunus)

Based on figures 11 and 12 above, it can be seen that the syllable "pa" in the word "lupa" both Heidi Yunus and Zahrotul Fauziah use improvisation by developing the main tone but different ways of performing it. Zahrotul Fauziah performed it with the tone Fis / $\mathrm{mi}$ (on A scale of 2 sharp), A / sol, fis / mi, B / la, and A / sol while Hedi Yunus performed it with the tone As / do (scale of $4 \mathrm{~mol}$ ), f / la, es / sol, des / fa, and Es / sol, but they both end in sol notes. The song Prahara Cinta sung by Heidi Yunus uses a tempo of $92 \mathrm{bpm}$ while Zahrotul Fauziah uses keroncong accompaniment with a tempo of 90 $\mathrm{bpm}$. The tempo of the two singers is not much different, both are in the tempo area andante. The tempo that tends to be fast in Prahara Cinta song makes not all techniques can be applied because the tempo in keroncong tends to be slower.

Prahara Cinta song tells about someone who falls in love, always imagines his lover's face, and feels happy. The expression that has to be performed in singing the Prahara Cinta song should be cheerful. In performing this song, Zahrotul Fauziah is very energetic and delivers the content of the song well. There are some differences in performing this song by Heidi Yunus and Zahrotul Fauziah. Hedi Yunus performs it stably, does not use much dynamics, while Zahrotul Fauziah performs it more dynamics especially in the reference part.

The vocal performance of Zahrotul Fauziah in performing a popular song with a fast tempo tends to be stable or ngepop although it is accompanied using keroncong music accompaniment.

\section{CONCLUSION}

Based on the research and discussion, it can be concluded that the performance of popular songs by using keroncong music accompaniment with available techniques such as luk, nggandul, embat, gregel and cengkok, as well as pop singing techniques, like improvisation, each of the singers has different performance. When performing a popular song that has a slow tempo, the keroncong singers apply the techniques of singing keroncong song such as luk, nggandul, embat, gregel and cengkok freely or it is called ngeroncongi. Besides that, the vocal performance changes to be more tunable. While in performing a popular song that has a faster tempo, the keroncong singers tend to apply popular song singing technique or it is called ngepop because the techniques of keroncong singing are more difficult to be applied in faster tempo song.

\section{REFERENCES}

Ayunda, P. R., Gustina, S., \& Virgan, H. (2013). Gaya Menyanyi Pada Musik Keroncong Tugu (Analis Gaya Saartie Margaretha Michiels). Jurnal Antalogi Departemen Pendidikan Seni Musik FPSD UPI, 1(3).

Finalti, C. (2012). Kajian Teknik Vokal Gaya Keroncong Asli di Orkes Keroncong Surya Mataram Yogyakarta. Universitas Negeri Yogyakarta.

Ganap, V. (2006). Pengaruh Portugis pada Musik Keroncong. Harmonia, 02(4), 1-14.

Ganap, V. (2011). Keroncong Toegoe. BP ISI.

Ganap, Victor. (2011). Krontjong Toegoe. Badan Penerbit Institut Seni Indonesia Yogyakarta.

Ganap, Victor. (2020). Krontjong Toegoe: Asal-usul Musik Keroncong (I. Suhanda (ed.)). PT Kompas Media Nusantara.

Harmunah. (1987). MusikKeroncong :Sejarah, Gaya Dan Perkembangan. Pusat Musik Liturgi.

Harmunah. (1996). Musik Keroncong. Pusat Musik Liturgi.

Kornhauser, Bronia; Kartomi, M. J. (1978). In Defence of Kroncong. Studies in Indonesian Music, 104-183.

Kornhauser, B. (1984). In Defence Of Keroncong Dalam Dieter Mack. Sejarah Musik Jilid IV. Pusat Musik Liturgi.

Pambajeng, N. R. S., Suryati, S., \& Musmal, M. (2019). Teknik Vokal dan Pembawaan Lagu 
Keroncong Stambul "Tinggal Kengangan" Ciptaan Budiman BJ oleh Subarjo HS. In PROMUSIKA (Vol. 7, Issue 1, pp. 29-37). Institut Seni Indonesia Yogyakarta. https://doi.org/10.24821/promusika.v7i1.3166

Pranadjaja. (1976). Seni Menyanyi. C. V Baru.

Purba, M., \& Pasaribu, B. M. (2006). Musik Populer. Lembaga Pendidikan Seni Nusantara.

Putra, R. E. K., Rachman, A., Raharjo, E., \& Suharto, S. (2021). Interaksi Simbolik Pada Pertunjukan Musik Keroncong olehOrkes Keroncong Gunung Jati New Musik di Stasiun Tawang Semarang. Gondang: Jurnal Seni Dan Budaya, 5(1), 30-39. https://doi.org/https://doi.org/10.24114/gonda ng.v5i1.19996 Gondang:

Rachman, A. (2013). Bentuk dan Analisis Musik Keroncong Tanah Airku Karya Kelly Puspito. HARMONIA - Jurnal Pengetahuan Dan Pemikiran Seni, 13(1), 69-77.

Rachman, A., \& Lestari, W. (2013). Bentuk Aransemen Musik Keroncong Asli Karya Kelly Puspito dan Relevansinya Bagi Remaja dalam Mengembangkan Musik Keroncong Asli. Catharsis, 2(1), 1-11. http://journal.unnes.ac.id/sju/index.php/cathar sis

Rachman, A., \& Pribadi, S. E. (2019). Kroncong Music in Semarang: A Process of Enculturation. Ijal, 4(2), 1-9.

Rachman, A., \& Utomo, U. (2018a). "Sing Penting Keroncong": Sebuah Inovasi Pertunjukan Musik Keroncong di Semarang. Jurnal Pendidikan Dan Kajian Seni, 3(1), 47-64.

Rachman, A., \& Utomo, U. (2018b). "Sing Penting Keroncong": Sebuah Inovasi Pertunjukkan Musik Keroncong di Semarang. Jurnal Pendidikan Dan Kajian Seni, 3(1).

Rachman, A., \& Utomo, U. (2019). The Rhythm Pattern Adaptation of Langgam Jawa in Kroncong. Dvances in Social Science, Education and Humanities Research, Volume 276 2nd International Conference on Arts and Culture (ICONARC 2018), 276(Iconarc 2018), 99-101.
Rachman, A., Utomo, U., \& Asriyani, N. (2019). Penciptaan lagu keroncong berbasis kearifan lokal di kota semarang. JPKS: Jurnal Pendidikan Dan Kajian Seni, 4(2), 101-114.

Ramadhani, F. A., \& Rachman, A. (2019). Resistensi Musik Keroncong di Era Disrupsi: Studi Kasus pada O.K Gita Puspita di Kabupaten Tegal. Musikolastika: Jurnal Pertunjukan Dan Pendidikan Musik, 1(1), 4151.

Sanjaya, S. (2010). Pemahaman Dasar Musik Keroncong. Tjroeng Gelegak Jiwa Nusantara: Buletin Komunitas Keroncong. https://www.tjroeng.com/?s=gaya+Keroncong tasli

Sanjaya, S. (2018). New Composition Concept for Keroncong Music in the Oboe Concerto with Keroncong and Orchestra. In International Journal of Creative and Arts Studies (Vol. 5, Issue 2, pp. 75-85). Institut Seni Indonesia Yogyakarta.

https://doi.org/10.24821/ijcas.v5i2.2413

Sedyawati, E. (1992). Pertumbuhan Seni Pertunjukan. Sinar Harapan.

Soeharto. (1996a). Serba-serbi Keroncong. Mustika.

Soeharto, D. (1996b). Serba-Serbi Musik Keroncong. Musika.

Srinati, D. (terj). (2007). Popular Culture pengantar menuju teori Budaya Populer. Jeja.

Witkin, R. W. (2003). Adorno on Popular Culture. In Sociology The Journal of The British Sociological Association. Routledge Taylor \& Francis Group.

Witkin, R. W. (2013). Adorno on Music. Routledge Taylor \& Francis Group.

Zahrotul, F., \& Rachman, A. (2020). Aransemen Vokal Sebagai Identitas O.K Congrock 17 di Semarang. Gondang: Jurnal Seni Dan Budaya, 4(1). https://doi.org/https://doi.org/10.24114/gonda ng.v4i1.17951 